\title{
Het welzijn van het onderwijzend personeel in België in tijden van corona
}

Whitney Van den Brande en Jeroen Aussems

\section{Casus Hilde \\ Hilde werkt al 25 jaar als leerkracht in een grote scholengemeenschap in België. Door het coronavirus is de organisatie van haar lespakket sterk gewijzigd. De omschakeling naar het digitale platform is voor haar ontzettend moeilijk en dat zorgt voor veel werk- druk. Tijdens haar permanentieopdracht op school is ze erg bang om besmet te worden met het virus en het door te geven aan haar gezinsleden. Hierdoor voelt ze zich niet goed in haar vel, slaapt ze slecht en twiffelt ze om zich ziek te melden.}

Deze casus illustreert dat de coronacrisis naast fysieke gezondheidsklachten eveneens mentale gezondheidsklachten met zich meebrengt. Dat blijkt ook uit de eerste resultaten van de Belgische coronastudie van IDEWE, Externe Dienst voor Preventie en Bescherming op het Werk (EDPBW, zie kadertekst) en KU Leuven. Meer dan 6500 werkende Belgen werden bevraagd. $48 \%$ van de werkende Belgen kampte een maand na de eerste lockdown in april 2020 met angsten en depressieve gevoelens. Daarnaast verklaarde maar liefst 38\% van de respondenten slecht te functioneren. Specifiek voor de onderwijssector, gaf $43 \%$ van het personeel aan depressieve gevoelens en angst te ervaren. Verder voelde $41 \%$ zich minder tevreden over zijn job. ${ }^{1}$

Deze cijfers tonen aan dat het extra belangrijk is om het onderwijzend personeel te ondersteunen tijdens deze coronacrisis. In dit artikel geven we een antwoord op de vraag: hoe kunnen Externe Diensten voor Preventie en Bescherming op het Werk bijdragen aan het welzijn van het onderwijzend personeel in tijden van corona? Om
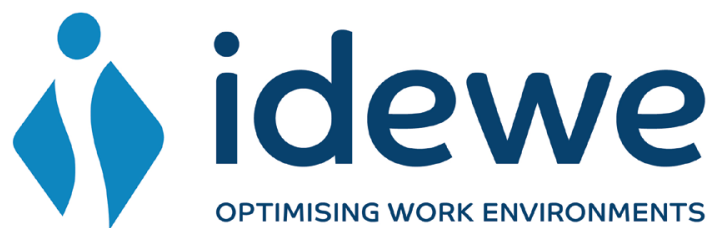

OPTIMISING WORK ENVIRONMENTS

deze vraag te beantwoorden werpen we een blik op het ondersteuningsaanbod dat de medewerkers van IDEWE uitwerkten tijdens de coronacrisis.

\section{Ondersteuningsaanbod}

EDPBW's kunnen onderwijsinstellingen bijstaan in het organiseren van hun werking tijdens een (corona)crisis; en daarmee werknemers zoals Hilde ondersteunen. Zo werden er binnen IDEWE diverse initiatieven opgestart:

\section{Gids Veilige en Gezonde Opstart Scholen}

De IDEWE preventieadviseurs ${ }^{2}$ brachten tijdens de eerste coronagolf in België de noden van onze onderwijsinstel-

\section{Wat is een EDPBW?}

Belgische Externe Diensten voor Preventie en Bescherming op het Werk zijn het best vergelijkbaar met Nederlandse arbodiensten, al hebben ze minder taken in verzuim en meer in preventie. Er zijn momenteel 11 EDPBW's in België. Belgische werkgevers sluiten zich aan bij een EDPBW om ondersteuning te krijgen in alle wettelijk verplichte opdrachten die het bedrijf heeft inzake preventie en bescherming op het werk. Een handvol zeer grote ondernemingen sluit zich niet aan bij een EDPBW maar organiseert de hele preventie intern, zij hebben dan een IDPBW. EDPBW's hebben multidisciplinaire teams met een arbeidsarts, arbeidsverpleegkundige, arbeidspsycholoog, hygiënist, ergonoom, en veiligheidsingenieur. In functie van de vragen en de noden bieden die multidisciplinaire teams kleine en grote bedrijven preventieve ondersteuning aan. 


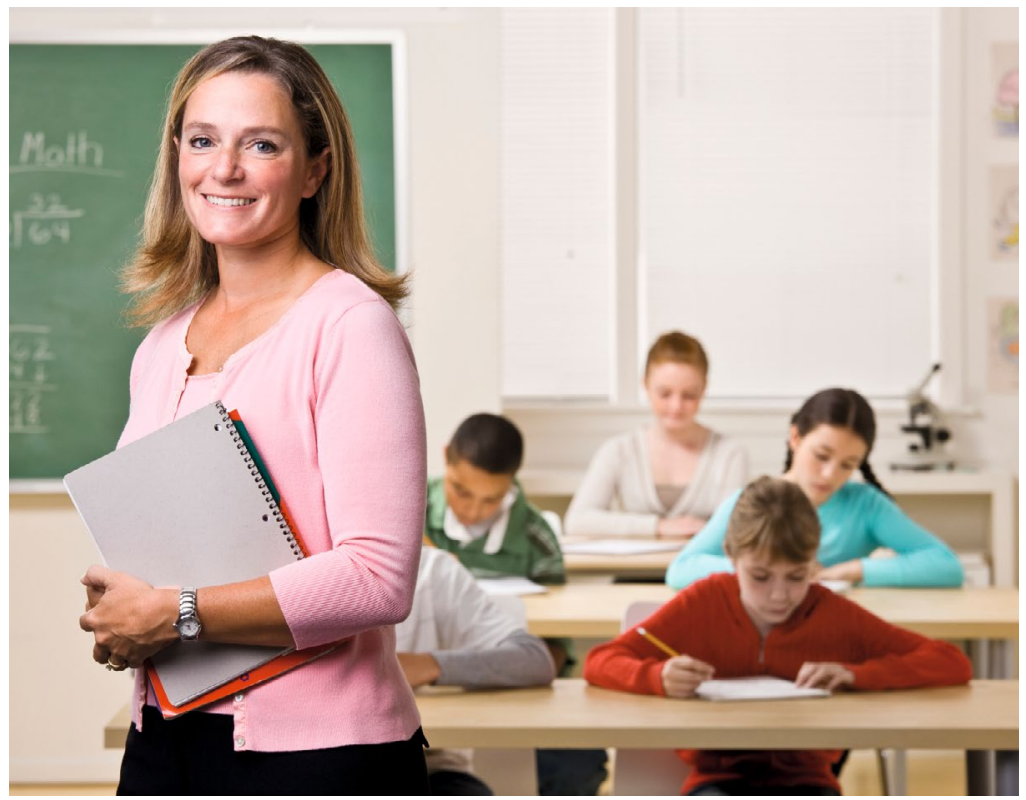

lingen in kaart. Eén van de grootste behoeften in het onderwijs was de behoefte naar duidelijkheid. Begin mei 2020 startte het onderwijs opnieuw op met de opvang van leerlingen. Daarna gingen ook de lessen weer van start. In deze fase was er nog veel onzekerheid. Vanuit het departement Volksgezondheid, het Departement Onderwijs en de verschillende onderwijskoepels werden diverse richtlijnen opgesteld. De richtlijnen baseerden zich op de inzichten die op dat moment beschikbaar waren. Deze inzichten lagen niet steeds in dezelfde lijn. Om in te spelen op de noden van de onderwijsinstellingen, ontwikkelde IDEWE een Gids Veilige en Gezonde Opstart Scholen met als doel onderwijsinstellingen te ondersteunen bij de heropstart en duidelijkheid te creëren. Deze gids bevat gevalideerde adviezen en richtlijnen gebaseerd op wetenschappelijke inzichten die afgestemd werden op de dagelijkse praktijk binnen de onderwijsinstellingen. De gids werd regelmatig aangepast aan de wijzigingen die de Belgische overheid communiceerde. Enerzijds informeerde de gids schoolbesturen en directies over de huidige richtlijnen, anderzijds werd er de nodige aandacht besteed aan het psychosociaal welzijn. Opstarten tijdens een pandemie met veranderingen in werkomgeving en -organisatie, is immers niet vanzelfsprekend. Zowel leerlingen opvangen voor en na schooltijd, als de combinatie tussen klassikale lessen en lesgeven via digitale platformen, vormden een grote mentale belasting voor het onderwijzend personeel.

\section{Webinars en sociale media}

De IDEWE-preventieadviseurs hielden nauw contact met de onderwijsinstellingen gedurende de hele periode. Onderwijsinstellingen vonden het belangrijk om gehoord te worden en vroegen naar mogelijkheden om hun bezorgdheden aan te kaarten. Om in te spelen op deze behoefte, koos IDEWE ervoor om naast rechtstreeks (telefonisch en/of online) contact, via webinars en sociale media in dialoog te gaan met onderwijsinstellingen. Het onderwijs in Vlaanderen startte tijdens de periode van Hemelvaartsdag in mei 2020 opnieuw op, in eerste instantie met een 'testdag' op vrijdag en een korte lesweek voor het verlengde weekend. Dat was een ideaal moment om de week daarna de dialoog op te zoeken met de onderwijsinstellingen. Hoe hadden ze die eerste dagen beleefd? Wat liep er goed? Wat moest bijgestuurd worden? Welke nieuwe inzichten waren er om de pandemie veilig en gezond het hoofd te bieden? Dit alles werd verwerkt in een nieuwe versie van de gids die tijdens een eerste webinar, met 750 deelnemers, werd voorgesteld. Enkele weken later volgde dan een Facebook livesessie met de expert infectiepreventie binnen IDEWE. Zowel gezondheids- en hygiënerisico's als het psychosociale welzijn kwamen aanbod tijdens het vraag- en antwoordmoment.

\section{Contact met het onderwijsnetwerk (online intervisies)}

IDEWE startte in april 2020 een digitaal netwerk op om de dialoog met de onderwijsinstellingen aan de gang te houden. Dit netwerk werd gebruikt om vinger aan de pols te houden in het onderwijs, en onze acties en inspanningen op te volgen en af te toetsen bij de doelgroep. Er vond tweewekelijks een overleg plaats met onderwijsexperten van IDEWE, grote scholengemeenschappen en koepelorganisaties binnen het onderwijs. Tijdens dit overleg kwam het psychosociaal welzijn telkens aan bod. De bezorgdheid bij de interne preventieadviseurs over het mentaal welbevinden van personeel en leerlingen was groot. Heel wat onderwijsinstellingen hebben op eigen initiatief hun personeelsleden bevraagd over de werkdruk en hun psychosociaal welzijn. Daar waar nodig bleek op basis van de resultaten werd de preventieadviseur psychosociale aspecten ingezet om ondersteuning te bieden. Niet alleen via individuele gesprekken, maar ook via groepsbegeleidingen en opleidingen.

\section{Fiches op basis van draaiboeken}

Op het einde van het schooljaar 2019-2020 vroegen we aan onze onderwijsinstellingen hoe ze onze

\section{Wat is een interne preventieadviseur?}

Dit is diegene die intern in het bedrijf verantwoordelijk is voor preventie. De interne preventieadviseur is het eerste aanspreekpunt op de werkvloer voor de medewerkers van een EDPBW. Meer info op: https://www. vlaanderen.be/werken/welzijn-en-gezondheid-op-hetwerk/preventieadviseur 
ondersteuning ervaren hadden en welke noden er aanwezig waren. De goede elementen (snel contact met arbeidsarts en psycholoog, nazicht risicoanalyse) bleven behouden. De verbeterpunten en (nieuwe) noden werden aangepakt. De gids in de eerste fase was uitvoerig en wijzigde zeer frequent, gezien het voortschrijdend inzicht. Dat maakte de te volgen richtlijnen niet altijd even duidelijk. Zo werd er geopteerd om voor de aanvang van het nieuwe schooljaar (2020-2021) in te zetten op informatiefiches (one-pagers) gelinkt aan de draaiboeken van de overheid met risicokleuren (geel, oranje en rood) per onderwijstype. Ook in deze fiches werd gewezen op het belang van goede en duidelijke communicatie om de onzekerheid en onveiligheid weg te nemen, twee elementen die bijdragen tot het welbevinden van personeelsleden en leerlingen. Dit communiceerden we opnieuw via een webinar ${ }^{3}$ waaraan 160 personen deelnamen.

\section{Digitale ondersteuning}

Vanuit het informatiecentrum van IDEWE konden de onderwijsinstellingen altijd rekenen op geactualiseerde werkdocumenten, brochures, affiches en sjablonen om de pandemie het hoofd te bieden. Dankzij deze bron aan informatie moesten onze onderwijsinstellingen geen tijd besteden aan het heruitvinden van het warm water. Ze konden zich zo focussen op het sensibiliseren en motiveren van hun personeelsleden en leerlingen. Sinds kort werd een monitoringstool toegevoegd waarbij de interne preventieadviseur en het schoolbestuur kunnen toetsen op welke manier het welzijnsbeleid kwalitatief in de scholen wordt uitgerold. Naast het focuspunt van de onderwijsdoorlichting binnenluchtkwaliteit, is er ook een rubriek rond psychosociaal welzijn opgenomen.

\section{StressBalañcer}

by isidewe

\section{StressBalancer op maat van het onderwijs}

Met het oog op de preventie van stress, uitputting en spanningen tussen collega's op het werk ontwikkelde IDEWE in samenwerking met KU Leuven de tool StressBalancer. StressBalancer is een e-learning tool die focust op de mentale weerbaarheid van individuele werknemers door hen aan te leren hoe ze op een actieve manier met stresserende werksituaties kunnen omgaan.

StressBalancer bestaat uit drie stappen. In Stap 1 (Stress Barometer) krijgt de werknemer een aantal vragen over zijn/haar werkbeleving en de manier waarop hij/zij omgaat met werkstressoren. In Stap 2 (Mijn Stress Profiel) krijgt de werknemer een persoonlijk stressprofiel met een overzicht van zijn/haar sterktes en groeipunten op het vlak van stressmanagement. In de laatste stap (Training) krijgt de werknemer een aantal oefeningen en tips aangeboden om op verschillende manieren met stresserende werksituaties om te gaan. Op het einde van dit e-learningtraject krijgt de werknemer een individueel adviesrapport toegestuurd. De preventie-effecten van StressBalancer werden in het verleden reeds aangetoond in een experimenteel interventieonderzoek (2017) waaraan 2873 werknemers deelnamen. ${ }^{4}$

De coronacrisis en het heropstarten van de scholen in mei 2020, na de eerste coronagolf en na de eerste lockdown, brachten voor het Belgische onderwijzend personeel heel wat mentale gezondheidsklachten met zich mee. Het is als EDPBW belangrijk om ook de mentale gezondheid van individuele werknemers in het onderwijs te ondersteu-

\section{A Stap 1: Stress Barometer}

\section{WERKCONTEXT}

Hoe vaak komt elk van deze situaties voor in jouw job?

\begin{tabular}{|c|c|c|c|c|c|}
\hline & (Bijna) nooit & Eerder zelden & Soms & Regelmatig & (Bijna) altijd \\
\hline $\begin{array}{l}\text { Ik word heen en weer geslingerd tussen mensen die andere } \\
\text { verwachtingen hebben in verband met mijn werk }\end{array}$ & • & 0 & 0 & 0 & 0 \\
\hline Ik krijg tegenstrijdige bevelen & $\bullet$ & • & ○ & - & - \\
\hline Ik krijg taken toegewezen die niet onder mijn functie vallen & - & • & - & - & - \\
\hline Ik weet precies wat anderen op mijn werk van mij verwachten & 0 & 0 & 0 & • & 0 \\
\hline
\end{tabular}




\section{Stap 2: Mijn Stress Profiel}

\section{WERKDRUK (1)}

Jouw huidige score

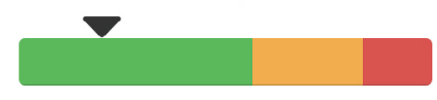

Jouw vorige score op 14/05/2020 $\checkmark$ Goed zo, doe zo verder!

Op het gebied van werkdruk bevind jij je in de groene zone. Je lijkt momenteel niet te veel werkdruk te ervaren. Dit is positief en dat willen we zo houden! Een te hoge werkdruk kan namelijk stress en spanningen tussen mensen op het werk met zich meebrengen.

In de volgende stap worden extra tips en oefeningen aangeboden om te leren omgaan met (onder meer) een te hoge werkdruk, moest je dit in de toekomst alsnog ervaren. nen. Daarom werd er een nieuwe module met oefeningen toegespitst op het onderwijs gratis beschikbaar gemaakt in onze e-tool StressBalancer. De extra module bevat onder meer oefeningen over de verhoogde werkdruk door het sterk gewijzigde lessenpakket (bijvoorbeeld afstandsonderwijs), over angstgevoelens, en over tegenstrijdige verwachtingen (bijvoorbeeld afstand houden versus kwalitatief onderwijs aanbieden). Er werden vooral oefeningen uitgewerkt met videofragmenten, foto's, tekstfragmenten en reflectiemomenten. In de eerste coronagolf, in het voorjaar van 2020, maakten 491 werknemers gebruik van de gratis module in StressBalancer.

\section{Lessons learned en suggesties voor de toekomst}

Uit de coronacrisis kunnen we veel lessen trekken. EDPBW's pasten hun dienstverlening aan, aan het nieuwe normaal om in te spelen op de huidige noden van organisaties. Voor de ondersteuning van onderwijsinstellingen kwam de EDPBW 'IDEWE' tot volgende inzichten:

- In tijden van crisis hebben de onderwijsinstellingen vooral nood aan eenduidige, gevalideerde informatie die eenvoudig consulteerbaar is.

- Door de coronacrisis en het wegvallen van het intern netwerk kan een EDPBW de rol van netwerkfacilitator opnemen. Op die manier houdt men vinger aan de pols, worden goede praktijken maximaal gedeeld met collega's en klanten en kan de dienstverlening op maat van de noden en behoeften aangepast worden.

- De ene opstart is de andere niet. Het is van belang om het voortschrijdend inzicht in de aanpak en in de advisering te blijven inbouwen. Op die manier werd StressBalancer tijdens de tweede coronagolf, in najaar 2020, opnieuw aangepast. De praktijkvoorbeelden werden geactualiseerd omdat de psychosociale belasting ook veranderd was. Dit resulteerde in nieuwe oefeningen om gebruikers uit te dagen duurzaam om te gaan met stress.

- Bij een crisis van deze omvang is het essentieel om het psychosociaal welzijn van personeelsleden niet alleen te monitoren, maar ook om personeelsleden te triggeren en te activeren om duurzaam om te gaan met stress. StressBalancer is een tool die hier maximaal op inzet. Het feit dat meer dan 400 onderwijzers hierop ingetekend hebben, geeft aan dat we als EDPBW een behoefte invulden.

Hoe kunnen EDPBW's dus bijdragen aan het welzijn van het onderwijzend personeel in tijden van corona? Vooral door actief te luisteren naar de huidige noden van onderwijsinstellingen en hierop in te spelen!

\section{Referenties}

1. Meer informatie beschikbaar via https://www.idewe.be/-/ eerste-resultaten-coronastudie

2. Voor een toelichting zie https://www.vlaanderen.be/werken/ welzijn-en-gezondheid-op-het-werk/preventieadviseur

3. Te herbekijken via https://idewe.webinarsolutions.tv/permalink/v125f648c3da665rtzvv/

4. Van den Brande W. (2018). Exploring the role of coping strategies and coping resources in the prevention of workplace bullying: The development of an online intervention, $\mathrm{PhD}$ Dissertation. 